\title{
Optimum parameters for humic acid removal and power production by Al-air fuel cell electrocoagulation in synthetic wastewater
}

\section{Wei Wei}

Anhui Jianzhu University

Haoyang Gong

Anhui Jianzhu University

Lin Sheng

Anhui Jianzhu University

Dong Zhou

Anhui Jianzhu University

Shuguang Zhu ( $\nabla 1780536279 @ q q . c o m$ )

Anhui Jianzhu University https://orcid.org/0000-0002-7404-8205

\section{Research Article}

Keywords: Aluminum-air fuel cell electrocoagulation, humic acid, wastewater treatment, power generation,

Posted Date: June 22nd, 2021

DOI: https://doi.org/10.21203/rs.3.rs-578503/v1

License: (c) (1) This work is licensed under a Creative Commons Attribution 4.0 International License. Read Full License

Version of Record: A version of this preprint was published at Water Science and Technology on November 29th, 2021. See the published version at https://doi.org/10.2166/wst.2021.495. 


\section{Abstract}

Although humic acid $(\mathrm{HA})$ is a complex natural organic matter, it can potentially harm the environment and human health. In this study, aluminum-air fuel cell electrocoagulation (AAFCEC) was used to remove HAs from water while generating electricity. This device can generate electricity from the anodic oxidation of aluminum without an external power source as well produce an aluminum coagulant. Operating parameters, namely initial $\mathrm{pH}$, electrolyte concentration, and $\mathrm{HA}$ concentration, were analyzed to determine the optimal power generation and removal efficiency. Al-Ferron complexation timed spectrophotometry was used to determine the Al speciation distribution in the solution. The power density of the cell reached $313.47 \mathrm{~mW} / \mathrm{cm}^{2}$ for the following conditions: $1 \mathrm{~g} / \mathrm{L} \mathrm{NaCl}$ concentration, $3 \mathrm{~cm}$ electrode distance, $20 \Omega$ external resistor, and pH 9. And after about an hour electrolysis, the optimum removal rate of HA was above $99 \%$. The results demonstrate that the AAFCEC is an efficient and ecofriendly water treatment process, and it could be further developed and disseminated in the rural areas and households.

\section{Introduction}

Humic acids (HAs) are complex natural organic matter formed from the remains of various plants and animals by anaerobic respiration of microorganisms in water, soil, and other environments(Afef et al.2019; Son et al.2019). HAs exist in large quantities in water, accounting for approximately $40-90 \%$ of the soluble organic pollutants in water (Hamed et al.2019). The main HA components are carbon, hydrogen, oxygen, nitrogen, and a small amount of phosphorus, sulfur, and other elements. HA has no fixed molecular structure. It is generally believed that the core structure of HA consists of aliphatic and aromatic parts, surrounded by various functional groups, such as hydroxyls, phenols, carboxyls, and ketones (Xie et al.2020; Liu et al.2020; Manuel et al.2020). These functional groups can adsorb organics and heavy metal ions in the water to form chelates that are difficult to remove (Zhang et al.2020; Zhou et al.2021). A large amount of HA can significantly affect the color, smell, and taste of water. In addition, HA in drinking water can form trihalomethanes, haloacetic acids, and other disinfection byproducts during the disinfection process, and these substances can potentially endanger human health (Aunnop et al.2018; Zhao et al.2020; Song et al.2019). Therefore, HAs should be removed from the water to reduce its potential harm to the environment and human body.

There are several techniques to remove HAs from water, including adsorption (Surendra et al.2020; Elham et al.2018), membrane filtration (Hwang et al. 2013), advanced oxidation (Yin et al.2020), ion exchange (Wang et al.2009), and coagulation (Xu et al.2016; Kanika et al.2019). However, these methods have some disadvantages, such as long processing time, high processing cost, difficult process control, and secondary pollution. Considering these problems, a more effective removal method is needed. According to previous research (Abdellatif et al.2020; Feride et al.2017), electrocoagulation (EC) is a technology that can effectively remove HA. EC is a simple and effective electrochemical process in which flocculants are produced by the electrolysis of metal anodes. As an eco-friendly water treatment technology, EC is widely used to remove various pollutants from water bodies, such as arsenic 
(Emilijan et al.2018; E. Şık et al.2017), chromium (A. Martín-Domínguez et al.2018), cadmium (Subramanyan et al.2011), phosphate (Adelaide et al.2019), nitric acid salts (Ismahane et al.2019), dyes (Murat et al.2009), fluorides (João et al.2018), and chemical oxygen demand (M. Elazzouzi et al.2017). Compared with traditional chemical coagulation, EC can generate coagulants through the electrolysis of metal anodes without the addition of chemicals. EC has the advantages of simple equipment requirement, convenient operation, easy control, and short running time. However, the operation of EC requires a large amount of electric energy, which limits its development. Therefore, it is necessary to reduce the power consumption of EC, thereby facilitating the application of this technology.

To reduce the EC power consumption, this study combines the concepts of metal-air fuel cells and electrocoagulation to design an aluminum-air fuel cell electrocoagulation (AAFCEC) equipment. The device, which consists of an aluminum anode and an air cathode, can generate electricity from the anodic oxidation of aluminum without an external power source, and it can also produce an aluminum coagulant. As a new type of energy cell, the aluminum-air fuel cell has the advantages of high specific energy and specific power, less harm to the environment, simple cell structure, safety, and reliability (Wu et al.2020; Petros et al.2020). The aluminum plate is used as the electrode because aluminum has advantages such as abundant reserves, low price, and nontoxicity (Wu et al.2020). In addition, the aluminum salt produced in the reaction is an effective coagulant and can potentially be used to remove pollutants from water. Aluminum-air batteries can generate electricity because of the low oxidation potential of aluminum and the relatively high reduction potential of oxygen. There is a potential difference between the two electrodes, which causes the electrons to continuously flow from negative to positive, thereby forming a continuous current. The reaction formula is shown in (1)-(3)(P. Goel et al.2020).

Anode: $\mathrm{Al}(\mathrm{s})+3 \mathrm{OH}^{-}(\mathrm{aq}) \rightarrow \mathrm{Al}(\mathrm{OH}) 3(\mathrm{~s})+3 \mathrm{e}^{-} \quad \mathrm{E}_{0}=-2.35 \mathrm{~V}(1)$

Cathode: $\mathrm{O}_{2}(\mathrm{~g})+2 \mathrm{H}_{2} \mathrm{O}(\mathrm{l})+4 \mathrm{e}^{-} \rightarrow 4 \mathrm{OH}^{-}(\mathrm{aq}) \quad \mathrm{E}_{0}=+0.40 \mathrm{~V}(2)$

Overall reaction: $4 \mathrm{Al}(\mathrm{s})+3 \mathrm{O}_{2}(\mathrm{~g})+6 \mathrm{H}_{2} \mathrm{O}(\mathrm{I}) \rightarrow 4 \mathrm{Al}(\mathrm{OH})_{3}(\mathrm{~s}) \quad \mathrm{E}_{0}=-2.75 \mathrm{~V}(3)$

The purpose of this study is to explore the feasibility and optimal conditions of an AAFCEC for the removal of HA from wastewater and to investigate the potential power generation of its cell. We investigated the influence of different parameters on electricity generation performance to determine the optimum conditions for power generation. We also determined the form of Al in the solution by using AlFerron complexation timed spectrophotometry. Subsequently, we investigated the removal efficiency of HA under different reaction conditions to determine the optimum removal conditions. Finally, we compared the results and proposed an appropriate set of parameters for an optimum balance between $\mathrm{HA}$ removal efficiency and power generation.

\section{Experiment And Methods}




\subsection{Sample}

The HA sample used in the experiments was artificially configured. HA was dissolved in deionized water in a beaker and continuously stirred with a magnetic agitator. The obtained solution was then filtered through a $0.45 \mu \mathrm{m}$ filter membrane, and the obtained filtrate was the HA stock solution, which was refrigerated. In the experiments, sodium chloride solution was used as the electrolyte, and $0.1 \mathrm{M} \mathrm{HCl}$ and $0.1 \mathrm{M} \mathrm{NaOH}$ were used to adjust the $\mathrm{pH}$ of the solution to prevent other ions from being introduced and affecting the experimental results. All materials used in the experiments were of analytical grade.

\subsection{Experimental setup and procedures}

The experimental device was a rectangular parallelepiped with size of $180 \mathrm{~mm} \times 30 \mathrm{~mm} \times 180 \mathrm{~mm}$, which was hollow inside in a cylinder format with diameter of $15 \mathrm{~mm}$ and height of $3 \mathrm{~cm}$. The front and rear sides were composed of square organic glass plates that formed a closed container. The effective volume of the device was $800 \mathrm{~mL}$. The aluminum plate anode $(100 \mathrm{~mm} \times 100 \mathrm{~mm} \times 0.25 \mathrm{~mm})$ was polished with sandpaper before the experiments and cleaned with absolute ethanol. The air electrode was composed of carbon black and activated carbon. Polytetrafluoroethylene was used as a binder. Platinum and copper were added as catalysts to the carbon powder of the catalytic layer. The carbon powder was laminated and fixed by a roller press on a nickel metal net.

In the experiment, a static aluminum-air fuel cell was constructed. Its power generation was explored by adjusting different parameters, such as $\mathrm{NaCl}$ concentration $(0.5,1,2$, and $3.5 \mathrm{~g} / \mathrm{L})$, initial pH $(5,6,7,8$, and 9), electrode distance $(3,6,9$, and $12 \mathrm{~cm})$, and external resistance $(10,20$, and $50 \Omega)$, which provided a technical basis for the subsequent experiments. Simultaneously, the total aluminum concentration and the aluminum form distribution were investigated under different conditions to determine the relationship between electricity production and aluminum production. The HA water sample was then placed in a beaker, and its $\mathrm{Ph}(5,6,7,8$ and 9$), \mathrm{NaCl}$ concentration( $0.5,1,2$, and $3.5 \mathrm{~g} / \mathrm{L})$, and initial concentration $(5 \mathrm{mg} / \mathrm{L}, 10 \mathrm{mg} / \mathrm{L}, 20 \mathrm{mg} / \mathrm{L}$ and $40 \mathrm{mg} / \mathrm{L})$ were adjusted to determine the removal efficiency. Subsequently, $10 \mathrm{~mL}$ HA solution was directly sampled from the beaker using a syringe at reaction times of $15,30,45,60,120$, and $180 \mathrm{~min}$. The samples were filtered through a $0.45 \mu \mathrm{m}$ filter membrane, and their respective HA content were measured. All the experiments were triplicate at least, and the average were been reported.

\subsection{Analysis and calculation}

The voltage of the resistor was collected by a data acquisition card connected to a computer. The data acquisition card collected voltage data every $0.5 \mathrm{~s}$, and all voltage values were stored in the computer for subsequent processing.

Linear sweep voltammetry was used to measure the power density and polarization curves using an electrochemical workstation with an aluminum anode as the working electrode, an air cathode as the counter electrode, and a saturated calomel electrode as the reference electrode. The measurement range 
was set from the open circuit voltage $(-0.7$ to $-0.8 \mathrm{~V})$ to $0 \mathrm{~V}$, and the sweep gradient was set to $0.01 \mathrm{~V}$. The current density (i) and power density $(P)$ were calculated using the following equations:

$\mathrm{i}=\mathrm{U} /(\mathrm{RA})$,

$P=i U$,

where $U$ is the voltage $(m V), R$ is the external resistance $(\Omega)$, and $A$ is the surface area of the anode $\left(\mathrm{cm}^{2}\right)$. Therefore, considering the current density as the abscissa and the power density as the ordinate, the power density curve was obtained.

The aluminum form was determined by Al-Ferron complexation timed spectrophotometry. The aluminum form can be divided into three types: Ala, Alb, and Alc. Ala is a monomer form of aluminum, and it mainly includes $\mathrm{Al}^{3+}$ and $\mathrm{AlOH}^{2+}$; $\mathrm{Alb}$ is a polymer form, mainly including $\mathrm{Al}_{2} \mathrm{OH}_{4}, \mathrm{Al}_{6} \mathrm{OH}_{12}$, and $\mathrm{Al}_{13} \mathrm{OH}_{32}$; Alc is the aluminum in the form of sol or gel, mainly including $\mathrm{Al}(\mathrm{OH})_{3}$. $\mathrm{UV}_{254}$ was measured with an ultraviolet spectrophotometer at a $254 \mathrm{~nm}$ wavelength to represent the HA concetration.

\section{Results And Discussion}

\subsection{Electrochemical analysis}

\subsubsection{Effect of electrolyte concentration}

The voltage values according to time for different $\mathrm{NaCl}$ concentrations are shown in Fig.1. Evidently, as the concentration of $\mathrm{NaCl}$ increases, the voltage also increases. When the $\mathrm{NaCl}$ concentration was $0.5,1$, 2 , and $3.5 \mathrm{~g} / \mathrm{L}$, the initial voltages were $145,207,257$, and $306 \mathrm{mV}$, respectively. This may be attributed to the solution conductivity, which increased with increasing electrolyte concentration. Therefore, the electron transfer rate increased correspondingly. In the first $15 \mathrm{~min}$ of reaction, the voltage increased slightly, after which it gradually stabilized. The stable voltages were 167, 229, 306, and $342 \mathrm{mV}$.

As shown in Fig.2(a), the maximum power density of the cell increased significantly as the electrolyte concentration increased. When the $\mathrm{NaCl}$ concentration was $0.5,1,2$, and $3.5 \mathrm{~g} / \mathrm{L}$, the corresponding maximum power densities were 108.97, $169.36,272.08$, and $427.59 \mathrm{~mW} / \mathrm{cm}^{2}$. These results are consistent with the changes in the anode potential. Fig.2(b) shows the polarization curves for different $\mathrm{NaCl}$ concentrations. When the $\mathrm{NaCl}$ concentration increased, the trend of the polarization curve was relatively smooth. This implies that for the same current density, the power generation is better at higher electrolyte concentrations.

Usually, the aluminum electrode surface is covered with a corrosion-protective film composed of oxide or hydroxide. The existence of this protective film hinders the charge transfer between electrode and solution, increasing the ohmic resistance and anode electrode potential. Therefore, proper removal of this protective layer is conducive to the electrode reaction. According to previous studies (Kim et 
al.2018; Kim et al.2017; Hubdar et al.2019), $\mathrm{NaCl}$ is one of the most effective electrolytes for such removal. The $\mathrm{Cl}^{-}$in the solution reacts with the protective film to accelerate the dissolution rate of the aluminum anode, as shown in formulas (6)-(10) (Hubdar et al.2018). Therefore, $\mathrm{NaCl}$ reduces the ohmic resistance of the electrolyte and improves the electron transfer efficiency. Consequently, the cell obtains a higher power density. These conclusions are consistent with our experimental results.

$$
\begin{aligned}
& \mathrm{Al}_{2} \mathrm{O}_{3}+6 \mathrm{Cl}^{-}+6 \mathrm{H}^{+} \rightarrow \mathrm{AlCl}_{3}+\mathrm{H}_{2} \mathrm{O}(6) \\
& \mathrm{Al}(\mathrm{OH})_{3}+\mathrm{Cl}^{-} \rightarrow \mathrm{Al}(\mathrm{OH})_{2} \mathrm{Cl}+\mathrm{OH}^{-}(7) \\
& \mathrm{Al}(\mathrm{OH})_{2} \mathrm{Cl}+\mathrm{Cl}^{-} \rightarrow \mathrm{Al}(\mathrm{OH}) \mathrm{Cl}_{2}+\mathrm{OH}^{-}(8) \\
& \mathrm{Al}(\mathrm{OH}) \mathrm{Cl}_{2}+\mathrm{Cl}^{-} \rightarrow \mathrm{AlCl}_{3}+\mathrm{OH}^{-}(9) \\
& \mathrm{AlCl}_{3}+\mathrm{Cl}^{-} \rightarrow \mathrm{AlCl}_{4}^{-}(10)
\end{aligned}
$$

\subsubsection{Effect of initial pH}

We explored the effects of initial pH on the power generation of the Al-air fuel cells. The changes in voltage according to time are shown in Fig.3. Weak acid or weak alkaline electrolytes were more conducive to electricity generation than that in the neutral electrolyte. In contrast, neutral electrolyte led to a relatively poor power generation performance. For an initial $\mathrm{pH}$ of 9 , the voltage was the highest, and the corresponding stable voltage reached $247 \mathrm{mV}$. When the initial pH was 5, the stable voltage reached $244 \mathrm{mV}$. The cell showed the worst performance at pH 7. Overall, the voltage was not significantly different at different initial $\mathrm{pH}$ values.

Similar results were observed for the power density curve and polarization curve. As shown in Fig.4(a), for initial $\mathrm{pH}$ of 9 , the power density was the maximum, reaching $326.10 \mathrm{~mW} / \mathrm{cm}^{2}$. At pH 5, the second highest power density of $313.47 \mathrm{~mW} / \mathrm{cm}^{2}$ was obtained. For initial $\mathrm{pH}$ of 7 , the power density was the smallest, at $267.807 \mathrm{~mW} / \mathrm{cm}^{2}$. The relative anode potentials at different initial $\mathrm{pH}$ values presented similar results. As shown in Fig.4(b), the anode potential for weak acid and alkaline electrolytes increased slowly, which is consistent with the results described above.

In other words, the electricity generation performance of the aluminum-air fuel cell was better in weak acid and alkaline electrolytes. This may been attributed to the corrosion protection layer on the surface of the aluminum anode, which reacts with the hydrogen or hydroxide ions in the weak acid and alkaline electrolyte, thereby dissolving the protection layer. Consequently, the cells obtained superior power generation. However, in a neutral electrolyte, the protective layer of the aluminum sheet hardly reacted, and the electricity generation performance was relatively poor.

\subsubsection{Effect of electrode distance and external resistance}


To explore the effect of electrode distance on cell power generation, experiments were performed with electrode spacing of $3,6,9$, and $12 \mathrm{~cm}$. Fig. 5 shows that the voltage decreased significantly with the increase in electrode distance. For the electrode distance of $3 \mathrm{~cm}$, the voltage reached its maximum, at approximately $300 \mathrm{mV}$. For electrode spacing of $12 \mathrm{~cm}$, the stable voltage reached only $190 \mathrm{mV}$. This occurred because the internal resistance increased with the electrode distance, thereby increasing the energy consumption(Khalid et al.2017; Khalid et al.2017; Khalid et al.2019). We used voltammetry to roughly measure the cell internal resistance; the results are shown in Fig.6. The slope of the fitted voltampere characteristic curve was used to roughly estimate the internal resistance of the fuel cell. For electrode distances of $3,6,9$, and $12 \mathrm{~cm}$, the internal resistances were approximately $12,18,25$, and $32 \Omega$, respectively. Therefore, electrode spacing significantly impacts the aluminum-air cell, and we set the electrode spacing to $3 \mathrm{~cm}$ in the subsequent experiments to obtain a better power generation.

We investigated the influence of external resistors on the power generation of the aluminum-air cell. The voltage and power according to time at different external resistances are shown in Fig.7. The highest voltages were obtained under external resistance of $50 \Omega$, reaching $420 \mathrm{mV}$; however, the output power was very low at that resistance. In contrast, lower voltages and higher powers were obtained at $10 \Omega$. Therefore, to provide a considerable output power and ensure a high stable voltage, the subsequent experiments used an external resistance of 20.

\subsection{Aluminum speciation}

Al species are crucial in the EC process as they determine the behavior and efficiency of Al-based coagulants (He et al.2016; Kong et al.2021). Formulas (1)-(3) show that the anode dissolves to generate $\mathrm{Al}^{3+}$ into the solution, and $\mathrm{Al}^{3+}$ is hydrolyzed to form various forms of compounds or polymers. The aluminum species is essential to determine whether the EC can remove HAs. This study investigates the optimum operating parameters according to the distribution of aluminum speciation in the solution.

Fig. 8 shows the distribution of aluminum speciation according to time for different $\mathrm{NaCl}$ solution concentrations at $\mathrm{pH} 5$. As the reaction progressed, the concentrations of Ala, Alb, and Alc gradually increased. The concentration of Alc increased quickly and reached the highest amount at the end. The contents of Ala and Alb were relatively low, and their growth was relatively slow, and it even presented a downward trend after some time. This can be explained by the fact that Ala and Alb in the solution are continuously converted into Alc as the reaction progresses. The final Al concentration indicates that all aluminum species in the solution increased with the $\mathrm{NaCl}$ concentration. When the $\mathrm{NaCl}$ concentration reached $3.5 \mathrm{~g} / \mathrm{L}$, the concentrations of Ala, Alb, and Alc reached 1.131, 8.145, and 16.147 mg/L, respectively.

To explore the effect of $\mathrm{pH}$ on the Al species, the initial solution $\mathrm{pH}$ was adjusted to $5,6,7,8$, and 9 using dilute hydrochloric acid and dilute sodium hydroxide. In the experiments, a $3.5 \mathrm{~g} / \mathrm{L} \mathrm{NaCl}$ solution was used as the electrolyte. Fig. 9 shows that the concentration of all Al species in the solution have increased. The total aluminum concentration was the highest at $\mathrm{pH}$ 9. As described in Section 3.1, the fuel cell 
presented the best electricity production performance at this $\mathrm{pH}$. In general, the total aluminum concentration did not significantly change according to $\mathrm{pH}$.

We also observed that the concentration of Alc was higher when the electrolyte was weakly alkaline. At $\mathrm{pH}$ 9, the concentration of Alc reached $20.163 \mathrm{mg} / \mathrm{L}$. The content of Ala and Alb in the weakly acidic electrolyte was relatively higher than that in the weakly alkaline electrolyte. This may be attributed to the hydrolysis reaction of $\mathrm{Al}^{3+}$. According to previous studies (Hu et al.2012), the main hydrolysis products of $\mathrm{Al}^{3+}$ are different at different $\mathrm{pH}$ values. This may be explained by the presence of $\mathrm{H}^{+}$, which inhibits the conversion of Ala to Alc in an acidic solution. Therefore, $\mathrm{Al}^{3+}$ and $\mathrm{AlOH}_{2}^{+}$were dominant in the solution. Moreover, as the $\mathrm{pH}$ value of the solution increases, the increase in $\mathrm{OH}^{-}$promoted the formation of $\mathrm{Al}(\mathrm{OH})_{3}$, and the concentration of Alc gradually increased.

\subsection{HA removal}

According to previous studies electrolyte (B.K. Zaied et al.2020; Hubdar et al. 2019), concentration is an important factor of EC. As shown in Fig.10(a), the HA removal efficiency significantly improved with increasing $\mathrm{NaCl}$ concentration. When the $\mathrm{NaCl}$ concentration was 3.5 and $2 \mathrm{~g} / \mathrm{L}$, the HA removal was over $90 \%$ in approximately 30 min of reaction. After approximately $40 \mathrm{~min}$, the HA removal rate was approximately $95 \%$ for all samples, except for those with $\mathrm{NaCl}$ concentration of $0.5 \mathrm{~g} / \mathrm{L}$. Therefore, the use of a higher concentration of $\mathrm{NaCl}$ solution can significantly improve the removal efficiency of the AAFCEC.

This phenomenon can be explained by the higher ion concentration in the solution, which significantly increases the conductivity, thereby significantly improving the transfer rate of electrons on the electrode surface (N.P.Tanattı et al.2018) . Correspondingly, the dissolution rate of the anode also increases, as well the amount of aluminum flocculant. $\mathrm{Cl}^{-}$has the potential to break down the protective layer at the surface of the metal anode electrodes to remarkably increase the current density (Kim et al.2015). In addition, as described in 3.2, the concentration of the $\mathrm{NaCl}$ solution also affects the speciation distribution of Al. As the concentration of the $\mathrm{NaCl}$ solution increases, the total aluminum concentration, especially the concentration of Alc, also significantly increases. According to previous studies (Sergi et al.2017), $\mathrm{Al}(\mathrm{OH}) 3$ is the main coagulant in Alc, and it is essential for the electro-flocculation process. According to our experiments, when the $\mathrm{NaCl}$ concentration is greater than $1 \mathrm{~g} / \mathrm{L}$, most $\mathrm{HAs}$ can be removed, and a higher power generation can be obtained. Therefore, considering the economic benefits, the subsequent experiments were performed using $1 \mathrm{~g} / \mathrm{L} \mathrm{NaCl}$ solution.

The effect of initial HA concentration is shown in Fig.10(b). We prepared HA samples of 5, 10, 20, and 40 $\mathrm{mg} / \mathrm{L}$ to investigate the effect of different HA concentrations on the removal efficiency. After $3 \mathrm{~h}$ of reaction, the HA removal rate in the solution at different initial concentrations surpassed $96 \%$. When the $\mathrm{HA}$ concentration was less than $20 \mathrm{mg} / \mathrm{L}$, the removal rate was higher than $90 \%$ after $60 \mathrm{~min}$. For this reaction time, the $40 \mathrm{mg} / \mathrm{L} \mathrm{HA}$ sample presented a removal rate smaller than $50 \%$. Therefore, $20 \mathrm{mg} / \mathrm{L}$ was the best initial HA concentration, and it was used in the subsequent experiments. 
The $\mathrm{pH}$ can significantly affect the EC process, which can affect the Al hydrolysate and HA structure (Antonio et al.2020; Ali et al.2008). The effect of HA removal at different pH values is shown in Fig.10(c). The initial $\mathrm{pH}$ value presented a certain effect on the HA removal. After the reaction proceeded for 120 min, the $U V_{254}$ values all dropped to a lower level, which indicated that the HAs were removed. Although the HA removal efficiency in the acidic solution was slightly higher than that in the alkaline solution, the overall difference was not significant. A relatively higher removal efficiency of HA was observed at pH 5 . This is also consistent with the results of previous studies (Antonio et al.2020). This phenomenon can be explained by the formation of a gel layer on the surface of the aluminum anode under high $\mathrm{pH}$ and high $\mathrm{HA}$ concentration. At pH 5, the presence of $\mathrm{H}^{+}$can inhibit the formation of the gel layer. In addition, as mentioned in Section 3.1, the aluminum-air fuel cell has a relatively good power generation at $\mathrm{pH} 5$. Furthermore, the total aluminum concentration in the solution is relatively high at this $\mathrm{pH}$. Therefore, $\mathrm{pH} 5$ was considered the optimum $\mathrm{pH}$ value.

\section{Conclusions}

In this study, we determined the optimal AAFCEC parameters for power generation and HA removal.Based on economic aspects and HA removal, we adjusted the relevant parameters to $1 \mathrm{~g} / \mathrm{L} \mathrm{NaCl}$ concentration, $\mathrm{pH} 5$, and initial HA concentration of $20 \mathrm{mg} / \mathrm{L}$, at which the power density reached $313.47 \mathrm{~mW} / \mathrm{cm}^{2}$, and the HA removal rate was over $99 \%$. Our results indicate that AAFCEC is a green and efficient water treatment process that can be used to remove HAs from water. And this device has a great advantage on wastewater treatment of rural areas or households because of its no need for external power supply.

\section{Declarations}

Ethics approval and consent to participate: Not applicable.

Consent to Publish: Not applicable.

Funding: This research was funded by University Natural Science Research Project of Anhui Province (CN) (NO.KJ2019A0756) ; Research Project Fund of Anhui Jianzhu University, Hefei, China (NO.2018QD08) and Natural Science Foundation of Anhui Province (CN) (NO. 1908085QE249); Key Research and Development Program of Anhui Province - General Key Project (201904a07020070).

Author Contributions: Conceptualization, Wei Wei; Formal analysis, Shuguang Zhu and Wei Wei; Funding acquisition, Wei Wei; Methodology, Haoyang Gong; Project administration, Haoyang Gong; Resources, Lin Sheng and Dong Zhou; Validation, Wei Wei; Writing - original draft, Haoyang Gong.

Conflicts of Interest: The authors declare that they have no known competing financial interests or personal relationships that could have appeared to influence the work reported in this paper.

Vailability of data and materials: All data generated or analysed during this study are included in this published article [and its supplementary information files]. And that the content of the article and the 
experimental data are authentic.

\section{References}

Abdellatif El-G, Mohammad A, Ahmed K, Ignasi S, Ahmed AW, Corrosion behavior of pure titanium anodes in saline medium and their performance for humic acid removal by electrocoagulation. Chemosphere 246 (2020) 125674. https://doi.org/10.1016/j.chemosphere.2019.125674

Adelaide D, Carmel B. B, Electrocoagulation using stainless steel anodes: Simultaneous removal of phosphates, Orange II and zinc ions, Journal of Hazardous Materials 374 (2019) 152158. https://doi.org/10.1016/j.jhazmat.2019.04.032

Afef B, Sana N, Amel C, Khaled B, Wided B, Elimame E,High-rate humic acid removal from cellulose and paper industry wastewaterby combining electrocoagulation process with adsorption onto granular activated carbon, Industrial Crops \& Products 140 (2019) 111715. https://doi.org/10.1016/j.indcrop.2019.111715

Ali Savas K, Yalcın SY, Bülent K, Nuhi D, Effect of initial pH on the removal of humic substances from wastewater by electrocoagulation, Separation and Purification Technology 59 (2008) 175182. https://doi.org/10.1016/j.seppur.2007.06.004

A. Martín-Domínguez, M.L. Rivera-Huerta, S. Pérez-Castrejón, S.E. Garrido-Hoyos, I.E. Villegas-Mendoza, S.L. Gelover-Santiago, P. Drogui b, G. Buelna, Chromium removal from drinking water by redox-assisted coagulation:Chemical versus electrocoagulation, Separation and Purification Technology 200 (2018) 266-272. https://doi.org/10.1016/j.seppur.2018.02.014

Antonio G. M, Brunno F. S, Artur S.C. R, Ronald R. H, Maurício L. T, Treatment of oily wastewater from mining industry using electrocoagulation: Fundamentals and process optimization, journal of materials research and technology 9 (2020) 15164-15176. https://doi.org/10.1016/j.jmrt.2020.10.107

Aunnop W, Pharkphum R, Alongorn S, Adisak S, Synthesis of porous Pig bone char as adsorbent for removal of DBPs precursors from surface water, Water Science \& Technology 486 (2018) 510589. https://doi.org/10.2166/wst.2018.486

B.K. Zaied, M. Rashid, M. Nasrullah, A.W. Zularisam, D. Pant, L. Singh, A comprehensive review on contaminants removal from pharmaceutical wastewater by electrocoagulation process, Science of the Total Environment 726 (2020) 138095. https://doi.org/10.1016/j.scitotenv.2020.138095

Elham D, Ali N, Optimization of humic acid removal by ad- sorption onto Bentonite and Montmorillonite nanoparticles, 259 (2018) 76-81. https://doi.org/10.1016/j.molliq.2018.03.014

Emilijan M, Srdjan R, Jasmina A, Kristiana Z, Aleksandra T, Božo D, Arsenic removal from groundwater by horizontal-flow continuous electrocoagulation (EC) as a standalone process, Journal of Environmental 
Chemical Engineering 6 (2018) 512-519. https://doi.org/10.1016/j.jece.2017.12.042

E. Şık, E. Demirbas b, A.Y. Goren, M.S. Oncel, M. Kobya, Arsenite and arsenate removals from groundwater by electrocoagulation using iron ball anodes: Influence of operating parameters, Journal of Water Process Engineering 18(2017) 83-91. http://dx.doi.org/10.1016/j.jwpe.2017.06.004

Feride UK, Mehmet K, Erhan G, Removal of humic acid by fixed-bed electrocoagulation reactor: Studies on modelling, adsorption kinetics and HPSEC analyses, Journal of Electroanalytical Chemistry 804 (2017) 199-211. http://dx.doi.org/10.1016/j.jelechem.2017.10.009

Hamed S, Amir HM, Kamyar Y, Abbas A, Kiomars S, Mahmood A, Mirzaman Z, Effect of modification by five different acids on pumice stone as natural and low-cost adsorbent for removal of humic acid from aqueous solutions - Application of response surface methodology, Journal of Molecular Liquids 290 (2019)111181. https://doi.org/10.1016/j.molliq.2019.111181

He Z, Lan H, Gong W, Liu R, Gao Y, Liu H, Qu J, Coagulation behaviors of aluminum salts towards fluoride:Significance of aluminum speciation and transformation, Separation and Purification Technology 165 (2016) 137-144. http://dx.doi.org/10.1016/j.seppur.2016.01.017

Hubdar AM, Kim JH, An BM, Park JY, Effects of supporting electrolytes in treatment of arsenatecontaining wastewater with power generation by aluminumair fuel cell electrocoagulation, Journal of Industrial and Engineering Chemistry 57 (2018) 254-262. http://dx.doi.org/10.1016/j.jiec.2017.08.031

Hubdar AM, Kim JH, Kim K, Park JY, Azmatullah K, Metal-air fuel cell electrocoagulation techniques for the treatment of arsenic in water, Journal of Cleaner Production 207 (2019) 67-

84. https://doi.org/10.1016/j.jclepro.2018.09.232

Hubdar AM, Lee J, Park JY, Kim JC, Kim KH, Kim JH, An energy-efficient air-breathing cathode electrocoagulation approach for the treatment of arsenite in aquatic systems, Journal of Industrial and Engineering Chemistry 73 (2019) 205-213. https://doi.org/10.1016/j.jiec.2019.01.026

Hu C, Liu H, Chen G, Qu J, Effect of aluminum speciation on arsenic removal during coagulation process, Separation and Purification Technology 86 (2012) 35-

40. http://dx.doi.org/10.1016/j.seppur.2011.10.017

Ismahane B, Mohamed B, Mohamed T, François L,Kenza B, Assessment of electrocoagulation based on nitrate removal, for treating and recycling the Saharan groundwater desalination reverse osmosis concentrate for a sustainable management of Albien resource, Journal of Environmental Chemical Engineering 7 (2019) 102951. https://doi.org/10.1016/j.jece.2019.102951

João F.A. Silva, Nuno S. Graça, Ana M. Ribeiro, Alírio E. Rodrigues, Electrocoagulation process for the removal of co-existent fluoride, arsenic and iron from contaminated drinking water, Separation and Purification Technology 197 (2018) 237-243. https://doi.org/10.1016/j.seppur.2017.12.055 
Kanika S, Urmila B, Aditya C, Coagulation of humic acid and kaolin at alkaline pH: Complex mechanisms and effect of fluctuating organics and turbidity, Journal of Water Process Engineering 31 (2019) 100875. https://doi.org/10.1016/j.jwpe.2019.100875

Khalid SH, Andy S, Rafid AK, Montserrat OP, David P, Defluoridation of drinking water using a new flow column-electrocoagulation reactor (FCER) - Experimental, statistical, and economic approach, Journal of Environmental Management 197 (2017) 80-88. http://dx.doi.org/10.1016/j.jenvman.2017.03.048

Khalid SH, Andy S, Rafid K, Montserrat OP, David P, Energy efficient electrocoagulation using a new flow column reactor to remove nitrate from drinking water e Experimental, statistical, and economic approach, Journal of Environmental Management 196 (2017) 224-

233. http://dx.doi.org/10.1016/j.jenvman.2017.03.017

Kim JH, An B, Lim DH, Park JY, Electricity production and phosphorous recovery as struvite from synthetic wastewater using magnesium-air fuel cell electrocoagulation, Water Research 132 (2018) 200-

210. https://doi.org/10.1016/j.mtener.2020.100499

Kim JH, Hubdar A M, Park JY, Treatment of synthetic arsenate wastewater with iron-air fuel cell electrocoagulation to supply drinking water and electricity in remote areas, Water Research 115 (2017) 278-286. http://dx.doi.org/10.1016/j.watres.2017.02.066

Kim JH, Park IS, Park JY, Electricity generation and recovery of iron hydroxides using a single chamber fuel cell with iron anode and air-cathode for electrocoagulation, Applied Energy 160 (2015) 1827. http://dx.doi.org/10.1016/j.apenergy.2015.09.041

Kong Y, Ma Y, Ding L, Ma J, Zhang H, Chen Z, Shen J, Coagulation behaviors of aluminum salts towards humic acid: detailed analysis of aluminum speciation and transformation, Separation and Purification Technology 259 (2021) 118137. https://doi.org/10.1016/j.seppur.2020.118137

Liu J, Fan J, He T, Xu X, Ai Yulu, Tang H, Gu H, Lu T, Liu Y, Liu G, The mechanism of aquatic photodegradation of organophosphorus sensitized by humic acid-Fe ${ }^{3+}$ complexes, Journal of Hazardous Materials 384 (2020) 121466.

https://doi.org/10.1016/j.jhazmat.2019.121466

Manuel G, Sergio C, Paula O, Mario D, The wet oxidation of aqueous humic acids, Journal of Hazardous Materials 396 (2020) 122402. https://doi.org/10.1016/j.jhazmat.2020.122402

M. Elazzouzi, Kh. Haboubi, M.S. Elyoubi, Electrocoagulation flocculation as a low-cost process for pollutants removal from urban wastewater, chemical engineering research and design 117 (2017) 614626. http://dx.doi.org/10.1016/j.cherd.2016.11.011 
Murat E, Mustafa K, Tugrul S A, Ebubekir Y, The effects of alternating current electrocoagulation on dye removal from aqueous solutions, Chemical Engineering Journal 153 (2009) 16-

22. https://doi.org/10.1016/j.cej.2009.05.028

N.P.Tanattı, I. A. Şengil, A. Özdemir, Optimizing TOC and COD removal for the biodiesel wastewater by electrocoagulation, Applied Water Science (2018) 8:58. https://doi.org/10.1007/s13201-018-0701-2

P. Goel, D. Dobhal, R.C. Sharma, Aluminum-air batteries: A viability review, Journal of Energy Storage 28 (2020) 101287. https://doi.org/10.1016/j.est.2020.101287

Petros K, Vasiliki M, Constantin P, George A, Panagiotis L, Study of some basic operation conditions of an Al-air cell using technical grade commercial aluminum, Journal of Power Sources 450 (2020) 227624. https://doi.org/10.1016/j.jpowsour.2019.227624

Sergi GS, Maria Maesia S.G. E, Jailson V de M, Carlos Alberto Martínez-Huitle, Electrocoagulation and advanced electrocoagulation processes: A general

review about the fundamentals, emerging applications and its association

with other technologies, Journal of Electroanalytical Chemistry 801 (2017) 267299. http://dx.doi.org/10.1016/j.jelechem.2017.07.047

Son $\mathrm{MH}$, Gong J, Seo S, Yoon H, Chang YS, Photosensitized diastereoisomer-specific degradation of hexabromocyclododecane (HBCD) in the presence of humic acid in aquatic systems, Journal of Hazardous Materials 369 (2019) 171-179. https://doi.org/10.1016/j.jhazmat.2019.02.035.

Song J, Jin X, Wang X C., Jin P, Preferential binding properties of carboxyl and hydroxyl groups with aluminium salts for humic acid removal, Chemosphere 234 (2019) 478-

487. https://doi.org/10.1016/j.chemosphere.2019.06.107

Subramanyan V, Jothinathan L, Ganapathy S, Effects of alternating and direct current in electrocoagulation process on the removal of cadmium from water, Journal of Hazardous Materials 192 (2011) 26-34. https://doi.org/10.1016/j.jhazmat.2011.04.081

Surendra SKJ, Ashish PU, Rajesh V, Sivakumar P, Manish KS, Swapnil D, Adsorptionandrecyclabilityaspectsofhumicacidusing nano-ZIF-8adsorbent, Environmental Technology \& Innovation 19 (2020) 100927. https://doi.org/10.1016/j.eti.2020.100927

Wang JN, Li AM, Zhou Y, Xu L, Study on the influence of humic acid of different molecular weight on basic ion exchange resin's adsorption capacity, Chinese Chemical Letters 20 (2009) 14781482. https://doi.org/10.1016/j.cclet.2009.07.013

Wu S, Zhang Q, Ma J, Sun D, Tang Y, Wang H, Interfacial design of Al electrode for efficient aluminum-air batteries:issues and advances, Materials Today Energy 18 (2020) 
Wu Z, Zhang H, Yang D, Zou J, Qin K, Ban C, Cui J, Hiromi N, Electrochemical behaviour and discharge characteristics of an Al-Zn-In-Sn anode for Al-air batteries in an alkaline electrolyte, Journal of Alloys and Compounds 837 (2020) 155599. https://doi.org/10.1016/j.jallcom.2020.155599

Xie L, Lu Q, Mao X, Wang J, Han L, Hu J, Lu Q, Wang Y, Zeng H, Probing the intermolecular interaction mechanisms between humic acid and different substrates with implications for its adsorption and removal in water treatment, Water Research 176 (2020)

115766. https://doi.org/10.1016/j.watres.2020.115766

Xu H, Jiao R, Xiao F, Wang D, Enhanced removal for humic-acid (HA) and coagulation process using carbon nanotubes (CNTs)/polyalumium chloride (PACl) composites coagulants, Colloids and Surfaces A: Physicochem. Eng. Aspects 490 (2016) 189-199. http://dx.doi.org/10.1016/j.colsurfa.2015.11.047

Yin H, Guo Q, Lei C, Chen W, Huang B, Electrochemical-driven carbocatalysis as highly efficient advanced oxidation processes for simultaneous removal of humic acid and $\mathrm{Cr}(\mathrm{VI})$, Chemical Engineering Journal 396 (2020) 125156. https://doi.org/10.1016/j.cej.2020.125156

Zhang J, Ning F, Kang M, Ma C, Qiu Z, Effective removal of humic acid from aqueous solution using adsorbents prepared from the modified waste bamboo powder, Microchemical Journal 153 (2020) 104272. https://doi.org/10.1016/j.microc.2019.104272

Zhao S, Sun Q, Gu Y, Yang W, Chen Y, Lin J, Dong M, Cheng H, Hu H, Guo Z, Enteromorpha prolifera polysaccharide based coagulant aid for humic acids removal and ultrafiltration membrane fouling control, International Journal of Biological Macromolecules 152 (2020) 576583. https://doi.org/10.1016/j.ijbiomac.2020.02.273

Zhou XF, Liang JP, Zhao ZL, Yuan H, Qiao JJ, Xu QN, Wang HL, Wang WC, Yang DZ, Ultra-high synergetic intensity for humic acid removal by coupling bubble discharge with activated carbon, Journal of Hazardous Materials 403 (2021) 123626. https://doi.org/10.1016/j.jhazmat.2020.123626

\section{Figures}

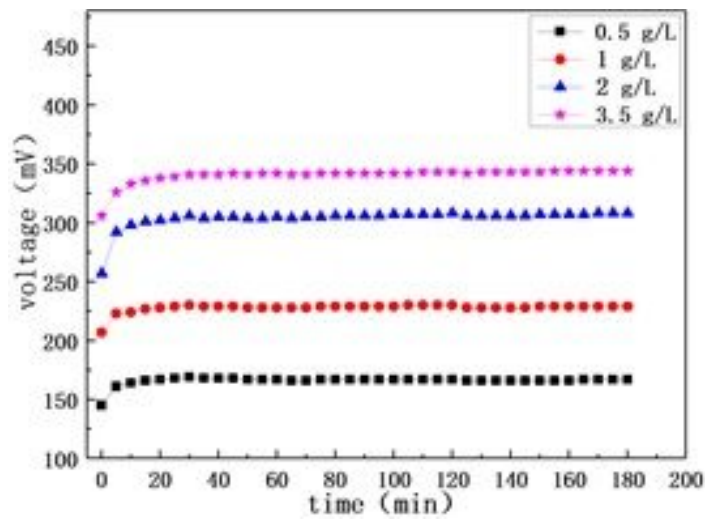


Figure 1

Voltage according to operation time for different $\mathrm{NaCl}$ concentrations
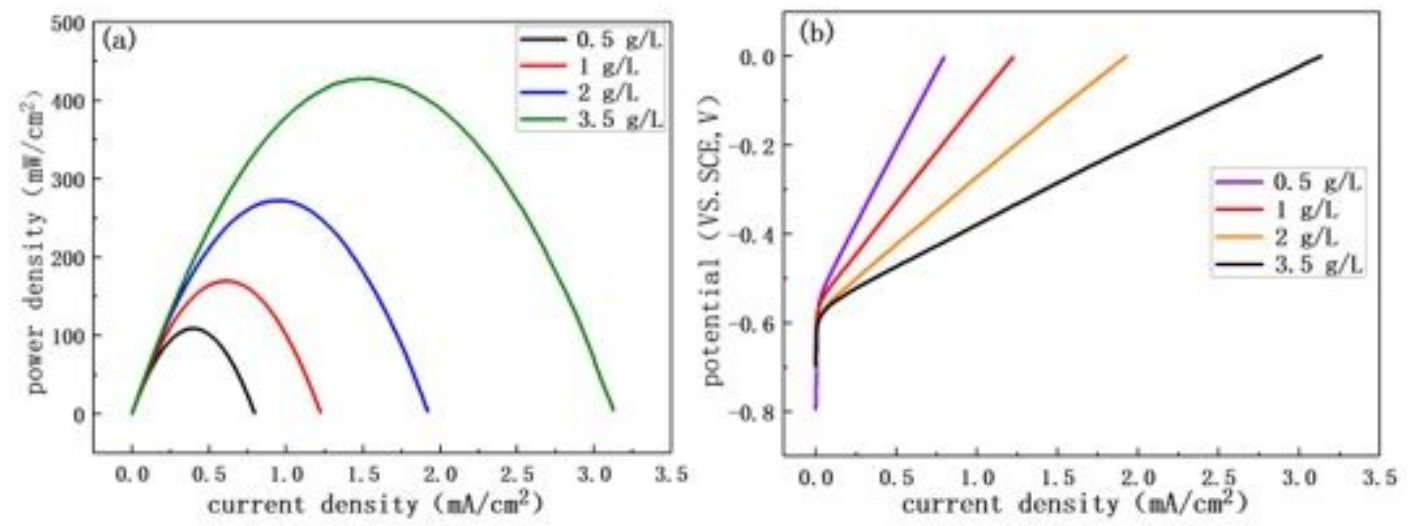

Figure 2

(a) Power density and (b) anode potential according to current density for different $\mathrm{NaCl}$ concentrations

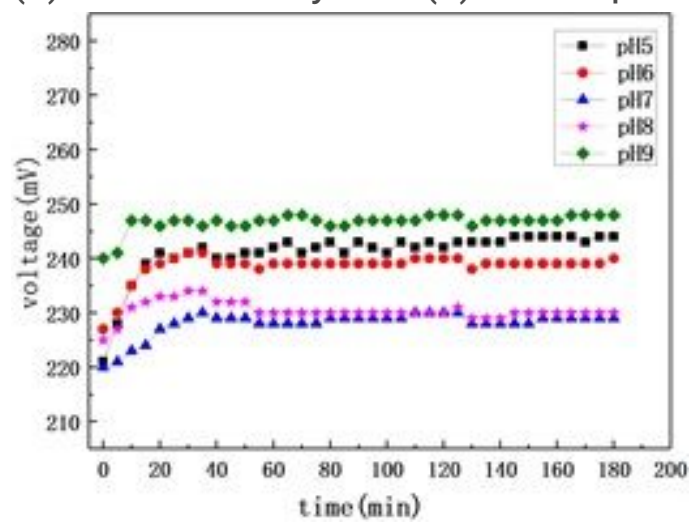

Figure 3

Voltage according to operation time for different initial $\mathrm{pH}$
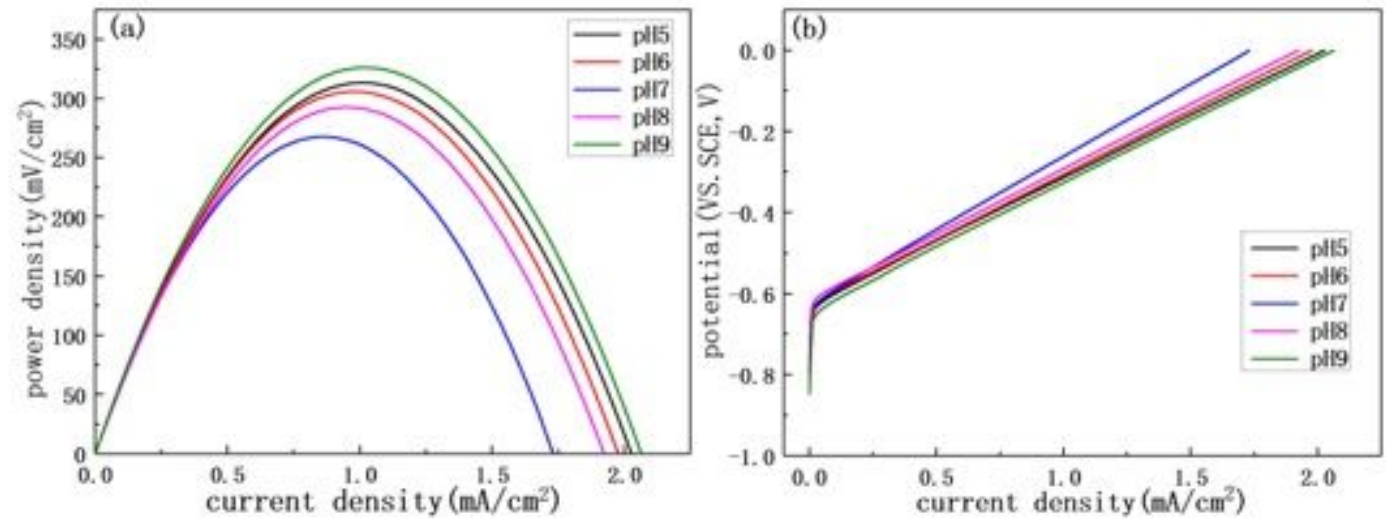

Figure 4

(a) Power density and (b) anode potential at different initial $\mathrm{pH}$ 


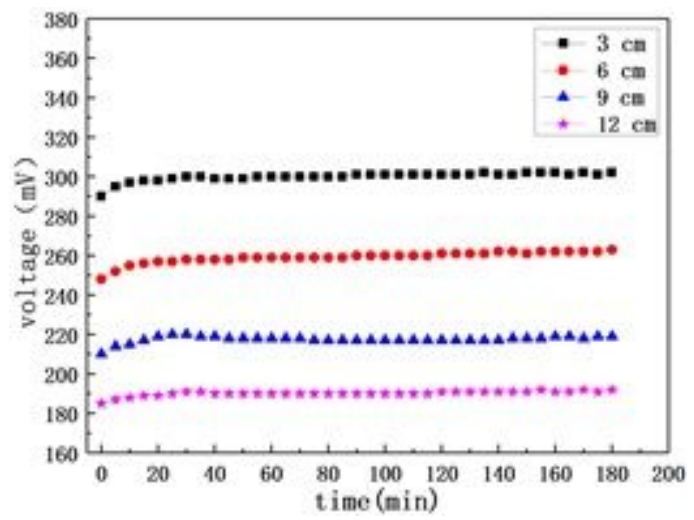

Figure 5

Voltage according to time for different electrode distance
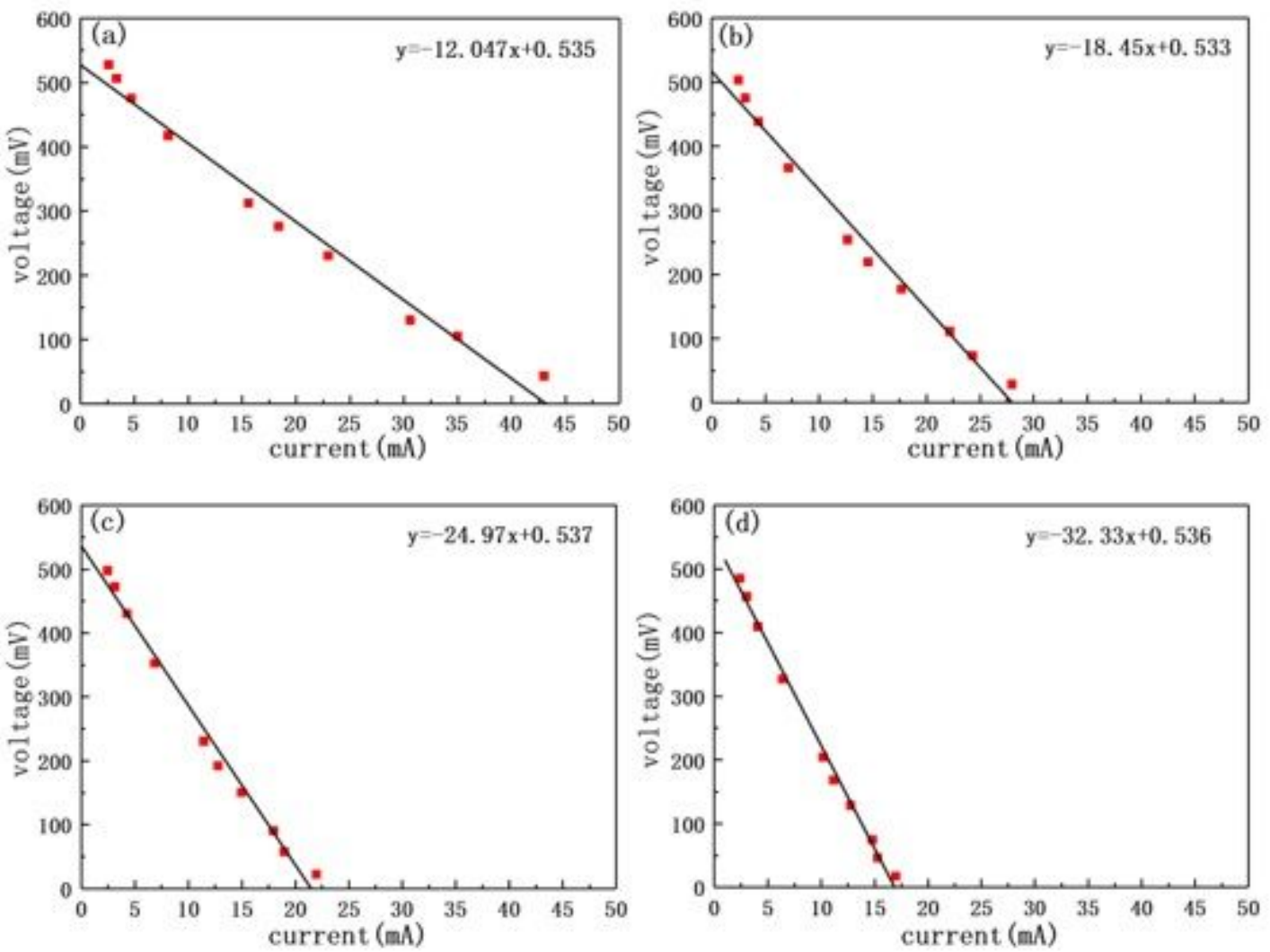

\section{Figure 6}

Volt-ampere characteristics for electrode distances of (a) 3, (b) 6, (c) 9, and (d) $12 \mathrm{~cm}$. 

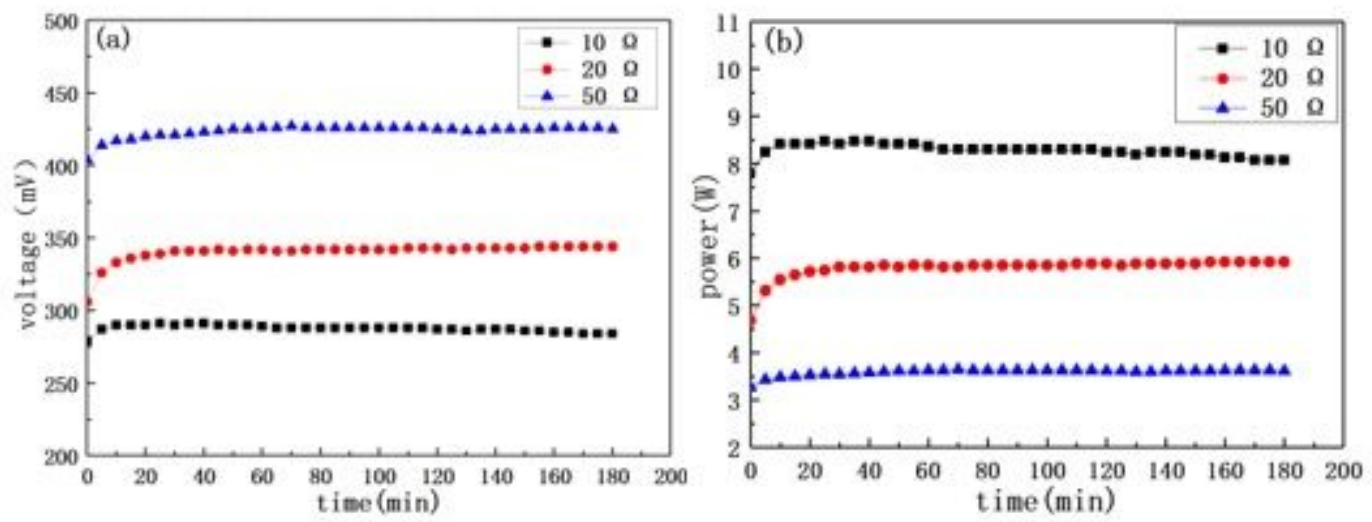

Figure 7

(a) Voltage and (b) output power according to time for different external resistance
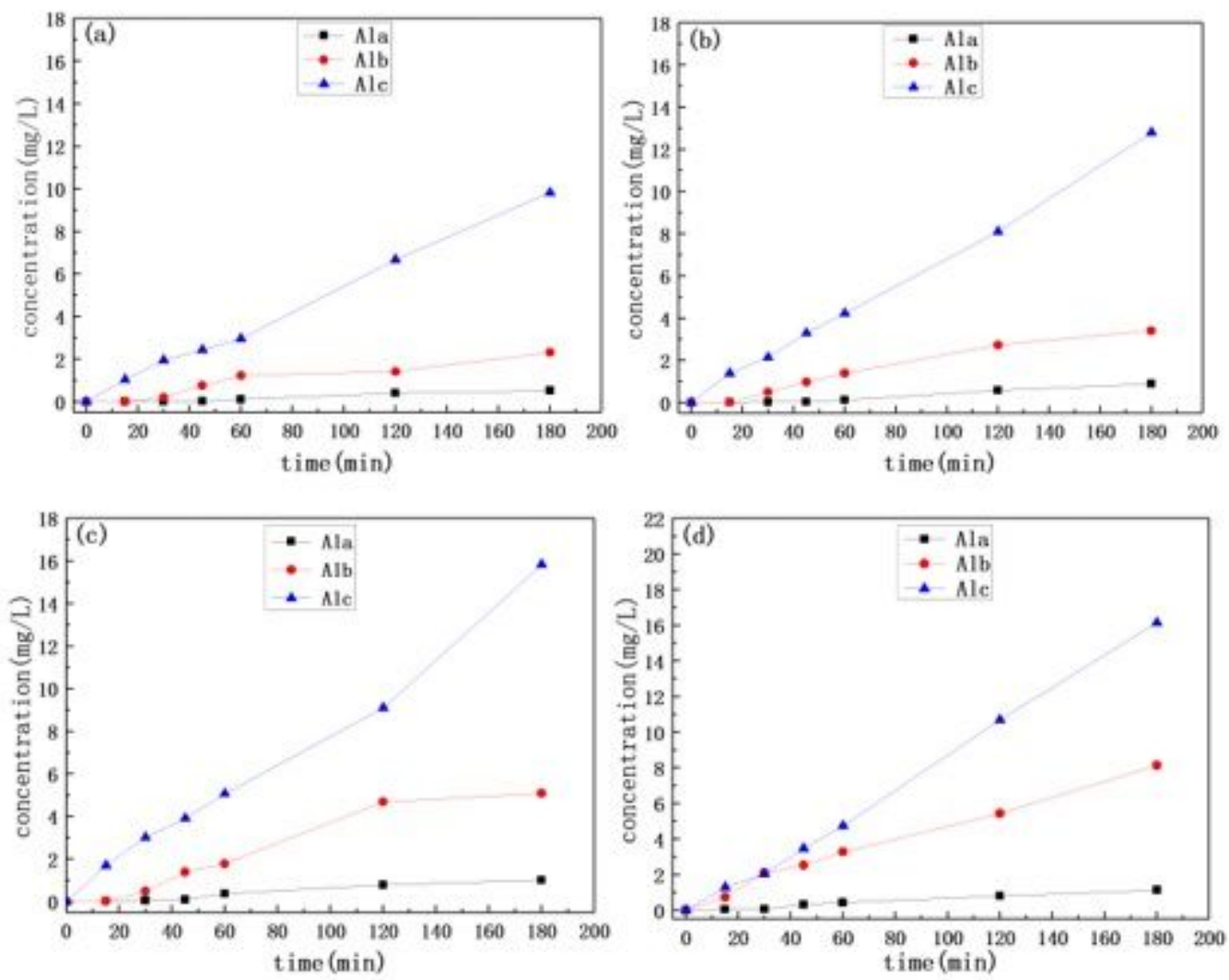

Figure 8

Aluminum speciation distribution according to time for $\mathrm{NaCl}$ solution concentrations of (a) 0.5, (b) 1 , (c) 2 , and (d) $3.5 \mathrm{~g} / \mathrm{L}$ 

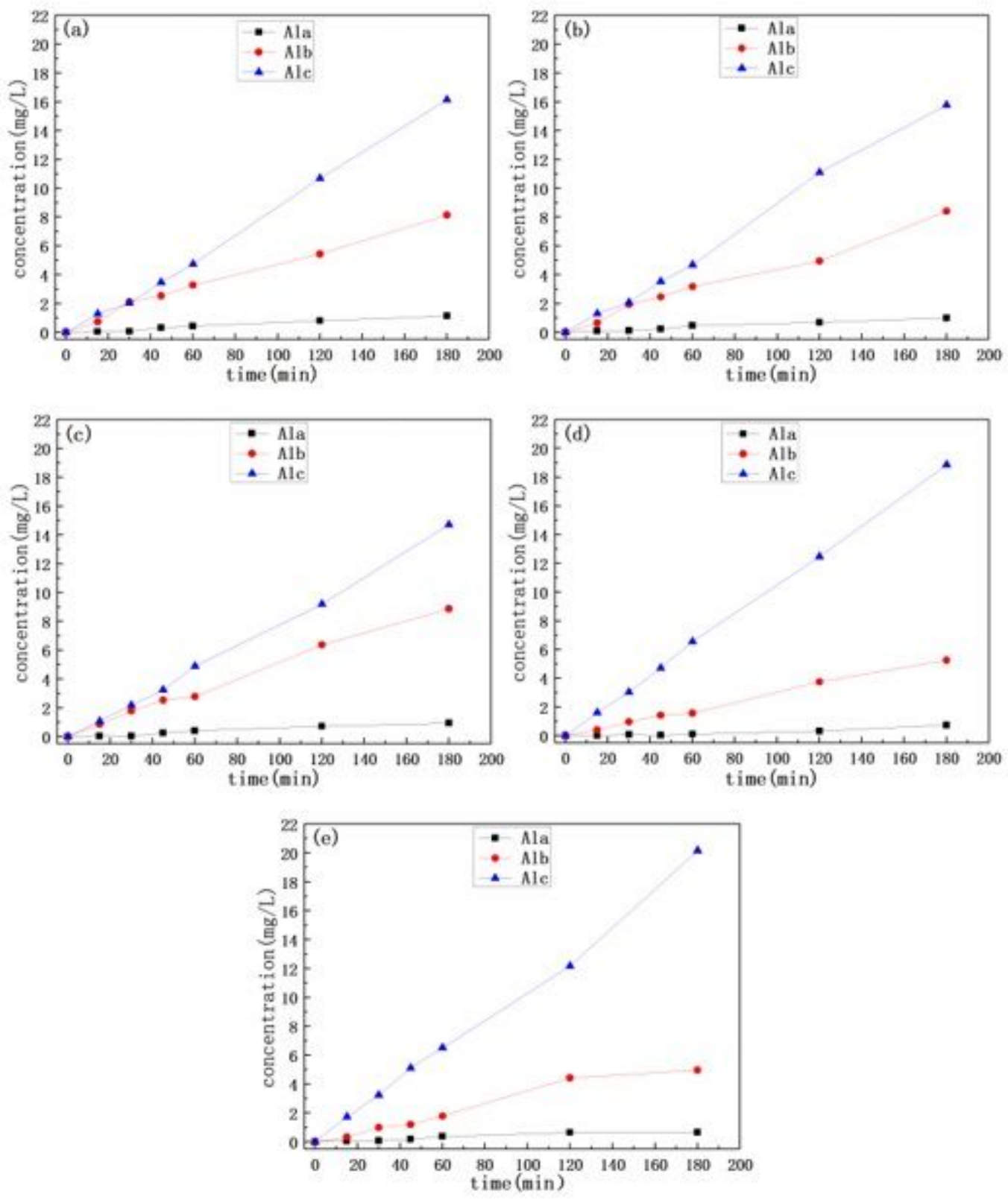

\section{Figure 9}

Aluminum speciation distribution according to time for different initial pH of (a) 5 , (b) 6 , (c) 7, (d) 8 , and (e) 9 

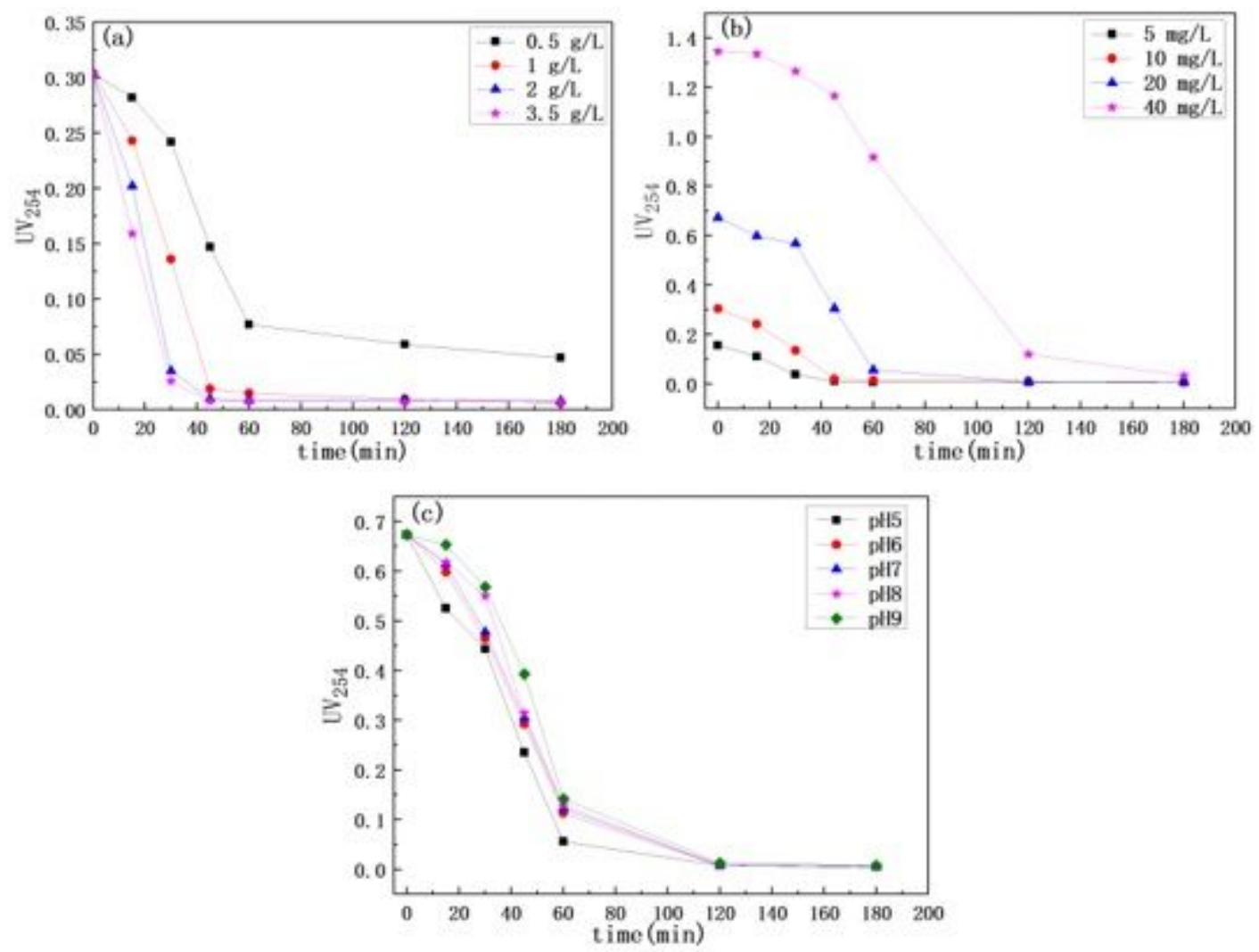

Figure 10

UV254 according to time under different parameters conditions: (a) NaCl concentration, (b) humic acid concentration, and (c) initial $\mathrm{pH}$

\section{Supplementary Files}

This is a list of supplementary files associated with this preprint. Click to download.

- GraphicalAbstract.docx 